\title{
Impacts of Bioactive Components Addition on Qualities of Imitation Crab Meat Containing Spent Laying Hen Meats During Storage
}

\author{
Sang-Keun Jin, Sun-Jin Hur ${ }^{1}$ and Teak-Soon, Shin $^{2 *}$ \\ Department of Animal Resources Technology, Jinju National University, Jinju, 660-758, Korea \\ ${ }^{1}$ Department of Food Science, University of Massachusetts Amherst, Amherst, MA. USA 01003 \\ ${ }^{2}$ Department of animal science, pusan national University, miryang, 627-706, Korea
}

Received November 3, 2009 / Accepted April 12, 2010

\begin{abstract}
Imitation crab stick samples were made from Alaska pollack with protein recovered from spent laying hens breast meat (C), Alaska pollack with spent laying hens breast recovered protein and cordyceps powder (T1), Alaska pollack with spent laying hens breast recovered protein and silkworm cocoon powder (T2), and Alaska pollack with spent laying hens breast recovered protein and conjugated linoleic acid (CLA) (T3). There were no significant differences in moisture, crude protein and crude fat among the imitation crab samples. $\mathrm{pH}$ was significantly higher in $\mathrm{T} 2$ and $\mathrm{T} 3$ compared with $\mathrm{C}$ and T1 after 4 weeks of storage. The values of $\mathrm{L}^{*}, \mathrm{a}^{*}, \mathrm{~b}^{*}$, and $\mathrm{W}$ (whiteness) in T3 were found to be more stable during storage and $\mathrm{W}$ in T3 was significantly higher than other samples. T3 was significantly lower in hardness, brittleness, gumminess and adhesiveness after 4 weeks of storage. Thiobarbituric acid reactive substance (TBA) values decreased with storage, whereas volatile basic nitron (VBN) values increased with storage periods in all samples. In sensory evaluation, there were no significant differences in color, odor, taste, tenderness, juiciness and overall acceptability among the samples. T3 was significantly lowest in quality among the treated samples.
\end{abstract}

Key words : Imitation crab, spent laying hens meat, bioactive components, meat quality

\section{서 론}

식품과 질병과의 연계성에 대한 소비자들의 관심이 급격히 증가함에 따라, 학계와 산업계에서는 기능성 식품소재 개발을 통한 국민건강 증진 및 질병예방을 위해 많은 연구가 활발히 진행되고 있다. 최근에는 천연물에 함유된 생리활성 성분에 대한 관심이 높아지면서 국내 - 외적으로 이들 생리활성 성분 을 함유한 신소재 식물들을 식품에 첨가하려는 시도가 많이 이루어지고 있는 추세이다. 특히, 생체조절기능이나 방어능력 이 있는 것으로 알려진 일부 성분들은 인체의 생리 기능조절 및 항상성 유지에 관여하여 질병예방이나 노화억제 등 건강을 유지하는데 주요한 역할을 하는 것으로 밝혀짐에 따라 이들을 이용한 기능성 축산물의 개발이 동물 및 식품산업의 새로운 연구 목표가 되고 있다[18,25]. 동충하초(冬蟲夏草)란 겨울에 는 벌레상태로 있다가 여름이면 버섯이 된다는 뜻에서 유래된 것으로 동충하초는 동충하초균이 곤충의 몸속에 들어가 죽이 고 얼마 후 자실체를 형성하는 약용버섯의 일종으로 중국에서 황달, 아편중독, 결핵, 암 및 천식 등 질병의 치료에 이용하였 으며, 면역기능 증강 그리고 항암 효과가 있는 것으로 보고되 었으며, 국내에서도 동충하초를 이용한 항암, 면역증강, 항피

\footnotetext{
*Corresponding author

Tel : +82-55-350-5514, Fax : +82-55-350-5519

E-mail : tsshin@pusan.ac.kr
}

로 등의 효과가 보고되었다 $[10,17,24]$. 또한, 자양강장효과, 면 역기능 증가 $[5,15,30]$ 항균성 및 항종양작용 $[13,22]$ 생체산화방 지[20], 혈당강화, 콜레스테롤과 중성지질 저하 효과[12] 등이 보고되어지고 있다. 우리나라에서는 1998년 농촌진훙청에서 누에동충하초(Peacilomyces Tenuipes)를 개발하여 식품원료로 사용승인을 받았으며[14], 그 기능성에 대해서 보고[7,27]된 바 있다. 현재까지 유용한 기능성 물질들이 밝혀져 식품이나 의 약품 분야에서는 여러 가지 생리적 활성을 지닌 건강지향적 식품소재로 개발되거나 연구가 진행되고 있지만, 아직까지 기 능성 측면에서의 과학적 연구는 초기수준에 머물러 있으며 $[8,11]$, 기능성을 함유한 축산물 생산에 적용시킨 연구는 거의 없는 실정이다. 누에고치의 주성분은 $30 \mathrm{kDa}$ 고분자 단백질인 피브로인(fibroin)으로 구성되어 가수분해, 중화, 분말화 과정 을 거쳐 로숀 등 화장품 재료, 음료수 등에 사용되며, 수술용 봉합사, 인공피부, 연질 콘텍트랜즈 등의 의료용 재료 또는 분해성 포장재료 등으로 응용하려는 연구가 시도되고 있다 [19]. Conjugated linoleic acid (CLA)는 다가불포화지방산의 일종인 linoleic acid에서 이중결합의 위치와 구조가 다른 이성 체를 일컷는 말로써 지방감소 효과, 항암, 항동맥 경화증, 당뇨 병 예방 및 치료에 대한 긍정적인 효과[23,28,31] 등 다양한 생리활성 효과가 보고되고 있다. 또한 CLA는 오랜기간 그 효 능이 과학적으로 검증되었고, linoleic acid로부터 화학적으로 값싸게 대량 합성할 수도 있으므로 생리활성 물질로써 이용가 
능성이 매우 높다고 할 수 있다. 따라서 본 연구에서는 폐계육 가슴살과 명태살을 이용하여 게맛살을 제조 시 동충하초 분말 과 CLA의 첨가가 게맛살의 품질특성에 미치는 효과를 구명함 으로써 폐자원의 이용효율을 높이고 생리활성 물질을 함유한 기능성 게맛살을 제조하기 위한 기초자료를 제공하는데 있다.

\section{재료 및 방법}

\section{게맛살의 제조}

게맛살 제조 배합비는 Table 1과 같으며, 제조방법은 Table 2에 준하여 진주산업대학교 축산가공연구실에서 제조하였다. 생리활성물질이 함유되지 않은 구를 대조구 $(\mathrm{C})$ 로 하여, 동충

Table 1. Experimental design

\begin{tabular}{|c|c|c|c|}
\hline \multirow{2}{*}{ Materials } & \multicolumn{3}{|c|}{ Quantity } \\
\hline & $\mathrm{T} 1$ & $\mathrm{~T} 2$ & T3 \\
\hline Alaska pollack surimi & \multicolumn{3}{|c|}{$4 \mathrm{~kg}$} \\
\hline Spent hens breast recovered protein & \multicolumn{3}{|c|}{$1 \mathrm{~kg}$} \\
\hline Ice & \multicolumn{3}{|c|}{$3 \mathrm{~kg}$} \\
\hline Salt & \multicolumn{3}{|c|}{$130 \mathrm{~g}$} \\
\hline Mixed ingredients ${ }^{1)}$ & \multicolumn{3}{|c|}{$350 \mathrm{~g}$} \\
\hline Mixed ingredients ${ }^{2}$ & \multicolumn{3}{|c|}{$860 \mathrm{~g}$} \\
\hline Total & \multicolumn{3}{|c|}{$9.34 \mathrm{~kg}$} \\
\hline Cordyceps powder & $10 \mathrm{~g}$ & - & - \\
\hline Silkworm cocoon powder & - & $10 \mathrm{~g}$ & - \\
\hline CLA & - & - & $10 \mathrm{~g}$ \\
\hline \multicolumn{4}{|c|}{$\begin{array}{l}{ }^{1)} \text { Crab extract } 0.11 \text {, Seasonings } 0.1 \text {, Kelp extract } 0.05 \text {, Egg al- } \\
\text { bumen liquid } 0.03 \text {, Soybean oil } 0.03 \text {, Glycine } 0.03 \mathrm{~kg} \text {, Total } \\
350 \mathrm{~g} \text {. } \\
\text { 2) Potato starch } 0.25 \text {, Wheat starch } 0.25 \text {, Sugar } 0.13 \text {, Carrageenin } \\
0.05 \text {, Calcium carbonate } 0.09 \text {, Crab taste } 0.04 \text {, CME } 0.02 \text {, } \\
\text { Phosphate } 0.03 \mathrm{~kg} \text {, Total } 860 \mathrm{~g} \text {. }\end{array}$} \\
\hline \multicolumn{4}{|c|}{ Table 2. Manufacturing process of crab meat analog } \\
\hline \multicolumn{4}{|l|}{ Process } \\
\hline \\
\hline \multicolumn{4}{|c|}{ Silent cutter (surimi, water, starch, ingredients) } \\
\hline \multicolumn{4}{|l|}{ Sheet extrusion } \\
\hline \multicolumn{4}{|l|}{ Steam cooking $\left(95^{\circ} \mathrm{C}\right)$} \\
\hline \multicolumn{4}{|l|}{ Gas cooking } \\
\hline \multicolumn{4}{|l|}{ Cooling } \\
\hline \multicolumn{4}{|l|}{ Slitting $(1.2 \mathrm{~mm})$} \\
\hline \multicolumn{4}{|l|}{ Bundling or Rolling fiber bundle } \\
\hline \multicolumn{4}{|l|}{ Color (ap } \\
\hline \multicolumn{4}{|l|}{ Cutting } \\
\hline \multicolumn{4}{|l|}{ Vacuum packaging } \\
\hline \multicolumn{4}{|l|}{ Metal detection } \\
\hline \multicolumn{4}{|l|}{ Pasteurization $\left(95 \pm 2^{\circ} \mathrm{C}\right)$} \\
\hline \multicolumn{4}{|c|}{ Cooling (below $10^{\circ} \mathrm{C}$ central temp. of product) } \\
\hline Storage (below $10^{\circ} \mathrm{C}$ ) & & & \\
\hline
\end{tabular}

하초분말을 함유한 구를 $\mathrm{T} 1$, 누에고치분말을 함유한 구를 $\mathrm{T} 2$ 그리고 $\mathrm{CLA}$ 를 함유한 구를 $\mathrm{T} 3$ 로 하여 진공포장(Cryovac, $60 \mu \mathrm{m}, \mathrm{BB} 4 \mathrm{~L}$, Japan) 후 $9 \pm 1^{\circ} \mathrm{C}$ 에서 4 주간 저장하면서 일반성 분, $\mathrm{pH}$, 보수력(가열전 시료), 가열감량(가열전 시료), 육색, 전단가, 조직감(전항목), 파괴강도, 변형값, 겔강도, 젤리강도, 관능검사(육색, 향, 풍미, 다즙성, 연도 및 전체적 기호도) 등 품질 특성을 분석하였다.

\section{일반성분(Proximate compositions)}

일반성분은 $\mathrm{AOAC}$ (1990) 방법에 따라 수분은 건조법, 조단 백질 함량은 Micro Kjeldahl 방법, 조지방 함량은 Soxhlet 추출 법 및 조회분 함량은 전기회화로를 이용하여 측정하였다.

\section{$\mathrm{pH}$}

$\mathrm{pH}$ 는 시료 $3 \mathrm{~g}$ 을 증류수 $27 \mathrm{ml}$ 와 함께 homogenizer (T25B, IKA Sdn. Bhd., Malaysia)로 14,000 rpm에서 10초간 균질하여 $\mathrm{pH}$ meter (8603, Metrohm, Swiss)로 측정하였다.

\section{보수력(Water Holding Capacity)}

보수력은 마쇄한 시료를 $70^{\circ} \mathrm{C}$ 의 항온수조에서 30 분간 가열 한 다음 냉각하여 $800 \times \mathrm{g}$ 에서 10 분간 원심분리한 후 무게를 측정하여 (시료 무게-유리수분 무게)/시료무게 $\times 100$ 의 식으로 계산하였다.

\section{가열감량(Cooking loss)}

가열감량은 시료를 2.0 (가로 $) \times 5.0$ (세로 $) \times 1.0$ (높이) $\mathrm{cm}$ 크기 로 절단하여 무게를 측정한 다음, zipper bag에 넣고 water bath에서 심부온도가 $75^{\circ} \mathrm{C}$ 에 도달할 때까지 가열한 후 실온에 서 완전히 식힌 다음 시료의 무게를 측정하여(가열 전 시료무 게-가열 후 시료무게)/가열 전 시료무게× 100 의 식으로 계산하 였다.

\section{전단가 및 조직감(Shear force and texture properties)} 전단가 및 조직감은 Instron 3343 (US/MX50, A\&D Co., USA) 을 이용하여 측정하였다. 전단가는 시료를 게맛살 결방향과 수평으로 $\varnothing 16.50 \times 20.00 \mathrm{~mm}$ 로 자른 후 결과 직각방향으로 knife형 plunger를 이용하여 절단하여 9반복 측정하였다. 이 때 측정 조건은 load cell $10 \mathrm{~kg}$, adapter area $30 \mathrm{~mm}^{2}$ 이었다. 조직감은 2.0 (가로) $\times 2.0$ (세로) $\times 1.0 \mathrm{~cm}$ (높이)로 썰어 plunger No. 3으로 근육방향과 직각이 되게 한 상태에서 경도(hardness), 표 면경도(brittleness), 응집성(cohesiveness), 검성(gumminess), 씹힘성(chewiness), 탄력성(springiness), 부착성(adhesiveness)을 측정하였다. 이 때 분석조건은 전단가 및 조직감 공히 chart speed $120 \mathrm{~mm} / \mathrm{min}$, maximum load $10 \mathrm{~kg}$, 측정속도 $60 \mathrm{~mm} / \mathrm{min}$ 로 하였다. 


\section{육색 $\left(\mathrm{L}^{*}, \mathrm{a}^{*}, \mathrm{~b}^{*}\right.$ and $\left.\mathrm{W}\right)$}

육색은 포장을 개봉한 후 30 분간 홍색화(blooming)를 실시 하고 표면의 수분을 제거하고 Minolta Chromameter (Minolta Co. CR-300, Japan)를 사용하여 동일한 방법으로 9회 반복하 여 명도(Lightness)를 나타내는 L"값, 적색도(Redness)를 나타 내는 $\mathrm{a}^{*}$ 값과 황색도(Yellowness)를 나타내는 $\mathrm{b}^{*}$ 값을 측정하였다. 기기의 표준화 작업은 $\mathrm{Y}=93.5, \mathrm{X}=0.3132, \mathrm{y}=0.3198$ 인 표준색판 을 사용하였다. 백색도(Whiteness)는 $\mathrm{L}^{*}-3 \mathrm{~b}^{*}$ 로 계산하였다.

\section{물리적 특성 (Gel characteristics)}

물리적 특성은 실린더형 시료 $(\varnothing 1.8 \times 2.0 \mathrm{~cm})$ 위에 지름 5 $\mathrm{mm}$ 구형 plunger를 장착하고 $60 \mathrm{~mm} / \mathrm{min}$ 의 속도로 Rheometer (EZ-Test, Shimadzu, Tokyo, Japan) 파괴강도 (breaking force) 변형도(deformatin), 겔 강도(gel strength) 및 젤리 강도(jelly strength)를 측정하였다.

\section{지방산패도(Thiobarbituric Acid Reactive Substances: TBA)}

지방산패도(TBA)는 Burge와 Aust (1978)의 방법으로 측정 하였으며, 육을 적당한 크기로 절단하고 $3 \mathrm{~mm}$ 플레이트로 분쇄한 후, 분쇄한 돈육 시료 $5 \mathrm{~g}$ 에 BHT (Butylated Hydroxytoluence) $50 \mu \mathrm{l}$ 와 증류수 $15 \mathrm{ml}$ 를 가해 homogenizer (IKA model T-25Basic, Malaysia)로 13,500 rpm에서 10초간 균질화 시켰다. 균질액 $2 \mathrm{ml}$ 에 TBA/TCA 혼합용액 $4 \mathrm{ml}$ 를 넣고 교반기에서 10 초간 혼합 후 $90^{\circ} \mathrm{C}$ water bath에서 15 분간 가열 반응시켰다. 냉각수로 식힌 시료는 $3,000 \mathrm{rmp}$ 에서 15 분 간 원심분리(Hanil model Union $5 \mathrm{kr}$, Korea)를 시킨 후 상층 을 회수하여 Spectrophotometer (Spectronic modelGenesys 5, U.S.A.)에서 $531 \mathrm{~nm}$ 의 흡광도를 측정하여 다음과 같은 계산식 에 의해서 나타내었다.

\section{$\mathrm{TBA}=\mathrm{Absorbance} \times 5.88$}

\section{휘발성염기질소(Volatile basic nitrogen)}

세절한 시료 $3 \mathrm{~g}$ 에 증류수 $27 \mathrm{ml}$ 를 가하여 $14,000 \mathrm{rpm}$ 에서 30초간 균질화한 후 Whatman No.1 여과지로 여과시켰다. 여 과액 $1 \mathrm{ml}$ 를 취하여 conway unit의 외실에 넣고, 내실에 0.01 $\mathrm{N}$ 붕산 $1.0 \mathrm{ml}$ 와 지시약 $(0.066 \%$ Methyl red $+0.066 \%$ Bromocresol green) 3 방울을 넣은 후 빨리 뚜껑을 닫고, 외실 에 $50 \% \mathrm{~K}_{2} \mathrm{CO}_{3} 1 \mathrm{ml}$ 를 재빨리 주입 후 바로 밀폐하여 용기를 수평으로 천천히 회전하여 외실의 시료와 $\mathrm{K}_{2} \mathrm{CO}_{3}$ 가 섞이게 하 였다. 시료는 $37^{\circ} \mathrm{C}$ 의 drying oven에서 120 분간 정치시킨 후 뚜껑을 열고 붕산용액을 $0.02 \mathrm{~N}-\mathrm{H}_{2} \mathrm{SO}_{4}$ 로 신속히 적정 하여 다음과 같은 계산식에 의해서 나타내었다.

$$
\begin{aligned}
& \text { (본시험의 적정치 }(\mathrm{ml})- \\
& \mathrm{VBNmg} \%(\mathrm{mg} / 100 \mathrm{~g} \text { 시료 })=\frac{\text { 공시험의 적정치 }(\mathrm{ml}) \times \mathrm{F} \times 28.014}{\text { 시료의 량 }(\mathrm{g})} \times 100
\end{aligned}
$$

F: $0.02 \mathrm{~N} \mathrm{H}_{2} \mathrm{SO}_{4}$ 표준화 지수 $=\frac{\text { 실제치 }}{\text { 이론치 }}$

28.014: $0.02 \mathrm{~N} \mathrm{H}_{2} \mathrm{SO}_{4} 1 \mathrm{ml}$ 소모하는데 필요한 $\mathrm{N}$ 의 양

\section{총 세균수(Total plate count)}

총 균수(Total bacterial counts)는 축산물 가공처리법(제 4 조 제 2항) 분석법에 준하여 시료 $10 \mathrm{~g}$ 을 $1 \%$ peptone수 $90 \mathrm{ml}$ 에 넣고 bagmixer로 균질시킨 다음 $1 \mathrm{ml}$ 를 채취하여 준비된 9 $\mathrm{ml}$ peptone수에 넣어 희석한 후, 희석액을 미리 조제한 배지 (plate counter agar, Difco)에 평판 배양하여 $32^{\circ} \mathrm{C}$ 에서 2 일 배 양한 후 나타나는 colony의 수를 계수 하였다.

\section{관능검사 (Sensory evaluation)}

관능검사는 Hedonic 방법에 준하여 훈련된 20대의 관능검 사요원 남자 8 명 여자 7 명 총 15 명을 선발하여 오후 3 시경에 각각 시험구별로 9점 척도법으로 관능검사를 실시하였다. 2.0 (가로 $) \times 2.0$ (세로) $\times 1.0$ (높이) $\mathrm{cm}$ 정도의 크기로 절단된 냉장상 태의 시료를 이용하였으며, 각 검사 요인별로 1 점은 매우 나쁘 거나 낮음(extremely bad or slight), 9점은 매우 좋거나 강함 (extremely good or much)으로 표시하였다.

\section{통계처리}

이상의 실험에서 얻어진 성적은 SAS/PC+(SAS. 1999)을 이 용하여 GLM (general linear model) 방법으로 분석하였고, 처 리 평균간의 비교를 위해 Duncan의 multiple range test가 이 용되었다.

\section{결과 및 고찰}

\section{일반성분}

동충하초 분말(T1), 누에고치 분말(T2) 및 CLA 첨가(T3)에 따른 폐계육 함유 게맛살의 일반성분 변화는 Table 3에 나타내 었다. 일반성분 함량 분석결과 제조 당시 시험구간 일반성분 의 유의적인 차이가 나타나지 않았으며, 제조당시 수분은 $70.32 \sim 74.33 \%$, 조지방은 $16.68-17.65 \%$, 조지방은 2.31 $4.71 \%$, 조회분은 $2.23 \sim 3.60 \%$ 수준으로 처리간 유의적인 차이 가 나타나지 않았다. 0 주 및 4 주째의 일반성분간의 비교에서 대조구의 조지방 함량이 급격한 감소하였으나(각각 $4.47 \%$, $2.68 \%)$ 유의적인 차이는 없었으며, 조단백질 및 조지방은 기간 에 따른 유의적인 차이가 나타나지 않았다. 4 주후 일반성분 분석에서 수분, 조단백질 및 조지방 함량은 시험구간 유의적 인 차이가 나타나지 않았으나, 조회분은 $\mathrm{T} 2$ 및 $\mathrm{T} 3$ 처리구가 대조구 및 $\mathrm{T} 1$ 처리구보다 유의적으로 낮은 조회분 함량을 나 타내었다 $(\mathrm{p}<0.05)$. 일반성분은 게맛살의 품질에 매우 큰 영향 을 미치는 요소이며, 특히 단백질의 함량과 수분의 함량은 게 
Table 3. Impact of functional components addition on proximate compositions (\%) of crab meat analog

\begin{tabular}{|c|c|c|c|c|c|c|}
\hline \multirow{2}{*}{ Items } & \multirow{2}{*}{ Storage } & \multicolumn{5}{|c|}{ Treatments $^{1)}$} \\
\hline & & C & $\mathrm{T} 1$ & $\mathrm{~T} 2$ & T3 & SE \\
\hline \multirow{3}{*}{ Moisture } & 1 day & 74.33 & 73.98 & 73.07 & 70.32 & 1.10 \\
\hline & 4 week & 74.11 & 73.34 & 73.41 & 73.42 & 0.12 \\
\hline & SE & 0.20 & 0.20 & 0.22 & 1.61 & \\
\hline \multirow{3}{*}{ Crude protein } & 1 day & $17.65^{\mathrm{a}}$ & 16.68 & 17.23 & 17.38 & 0.18 \\
\hline & 4 week & $16.85^{\mathrm{b}}$ & 16.73 & 16.59 & 17.28 & 0.19 \\
\hline & SE & 0.21 & 0.17 & 0.25 & 0.18 & \\
\hline \multirow{3}{*}{ Crude fat } & 1 day & 4.47 & 2.31 & 2.62 & 2.55 & 0.19 \\
\hline & 4 week & 2.68 & 2.60 & 2.50 & 2.86 & 0.09 \\
\hline & SE & 0.81 & 0.23 & 0.17 & 0.15 & \\
\hline \multirow{3}{*}{ Crude ash } & 1 day & 3.60 & $3.53^{b}$ & 3.02 & 2.23 & 0.33 \\
\hline & 4 week & $3.79^{\mathrm{A}}$ & $3.65^{\mathrm{Aa}}$ & $3.32^{\mathrm{B}}$ & $3.21^{\mathrm{C}}$ & 0.07 \\
\hline & SE & 0.06 & 0.03 & 0.09 & 0.46 & \\
\hline
\end{tabular}

${ }^{1)}$ Treatments are the same as in Table 1.

${ }^{A-C}$ Means with different superscripts in the same row significantly differ at $p<0.05$.

${ }^{\mathrm{a}-\mathrm{b}}$ Means with different superscripts in the same column significantly differ at $p<0.05$.

맛살의 품질에 가장 크게 영향을 미치는 요소이다[21,29]. Uddin 등(2006)은 수리미 제조를 위한 가장 적절한 수분의 함량은 $78 \%$ 정도라고 보고하였다. 그러나 본 실험에서 수분의 함량이 제조초기 70.32 74.33\%, 제조 4주째에 $73.34 \%$ $74.11 \%$ 로 다소 낮게 나타났다. 또한 본 실험에서 생리활성물 질의 첨가에 따라 일반성분 함량의 차이가 뚜렷하게 나타나지 않아 일반성분 함량이 폐계육 함유 게맛살의 일반성분에 큰 영향을 미치지 않은 것으로 사료된다.

\section{이화학적 특성}

기능성 물질 첨가에 따른 폐계육 함유 게맛살의 $\mathrm{pH}$, 보수 력, 가열감량 및 전단가 변화를 Table 4 에 나타내었다. 제조 초기 $\mathrm{pH}$ 는 $7.48 \sim 7.58$ 수준으로 시험구 간 유의적인 차이가
나타나지 않았다. 제조초기와 저장 4 주간의 비교에서 $\mathrm{T} 1$ 의 경 우 유의적인 $\mathrm{pH}$ 가 감소하였으며, 저장 4 주째의 $\mathrm{pH}$ 는 $\mathrm{T} 2$ 및 $\mathrm{T} 3$ 의 $\mathrm{pH}$ 가 대조구(6.95)에 비하여 유의적으로 높은 $\mathrm{pH}(7.42$ 7.54)를 나타내었다. 제조 초기 보수력은 대조구, T1 및 $\mathrm{T} 2$ 가 $94.90 \sim 95.87 \%$ 로 매우 높은 수준이었으나 T3는 다른 시험구 보다 유의적으로 낮은 $89.82 \%$ 수준이었다. 또한 제조초기 및 저장 4 주간의 보수력의 비교에서도 유의적인 변화가 없었으 며, 저장 4 주째의 보수력의 경우 시험구 간의 유의적인 보수력 의 차이가 나타나지 않아 93.02 94.75\%수준이었다. 제조초기 가열감량의 경우 대조구 및 T1 (10.00 10.62\%)이 T2 및 T3 (각각 $11.62 \%, 12.09 \%$ )보다 유의적으로 높게 나타났다 $(\mathrm{p}<0.05)$. 제조초기 및 저장 4 주간의 보수력의 비교에서 대조 구, $\mathrm{T} 1$ 및 $\mathrm{T} 2$ 는 저장 4 주차에 가열감량이 증가하였으나, $\mathrm{T} 3$ 는

Table 4. Impact of functional components addition on physico-chemical characteristics of crab meat analog

\begin{tabular}{|c|c|c|c|c|c|c|}
\hline \multirow{2}{*}{ Items } & \multirow{2}{*}{ Storage } & \multicolumn{5}{|c|}{ Treatments $^{1)}$} \\
\hline & & $\mathrm{C}$ & $\mathrm{T} 1$ & $\mathrm{~T} 2$ & T3 & SE \\
\hline \multirow{3}{*}{$\mathrm{pH}$} & 1 day & 7.58 & $7.56^{\mathrm{a}}$ & 7.49 & 7.48 & 0.02 \\
\hline & 4 week & $6.95^{\mathrm{B}}$ & $6.48^{\mathrm{Bb}}$ & $7.42^{\mathrm{A}}$ & $7.54^{\mathrm{A}}$ & 0.17 \\
\hline & SE & 0.18 & 0.24 & 0.04 & 0.03 & \\
\hline \multirow{3}{*}{ WHC (\%) } & 1 day & $94.90^{\mathrm{A}}$ & $95.87^{\mathrm{Aa}}$ & $95.04^{\mathrm{A}}$ & $89.82^{B}$ & 1.05 \\
\hline & 4 week & 94.73 & $94.05^{\mathrm{b}}$ & 93.70 & 93.02 & 0.68 \\
\hline & SE & 0.41 & 0.48 & 0.85 & 1.17 & \\
\hline \multirow{3}{*}{ Cooking loss (\%) } & 1 day & $10.62^{\mathrm{Bb}}$ & $10.00^{\mathrm{Bb}}$ & $11.62^{\mathrm{ABb}}$ & $12.09^{\mathrm{A}}$ & 0.43 \\
\hline & 4 week & $13.33^{\mathrm{a}}$ & $12.67^{\mathrm{a}}$ & $13.63^{\mathrm{a}}$ & 12.94 & 0.33 \\
\hline & SE & 0.69 & 0.72 & 0.52 & 0.47 & \\
\hline \multirow{3}{*}{$\begin{array}{c}\text { Shear force } \\
\left(\mathrm{kg} / \mathrm{cm}^{2}\right)\end{array}$} & 1 day & $0.53^{\mathrm{Ab}}$ & $0.43^{\mathrm{Ab}}$ & $0.40^{\mathrm{ABb}}$ & $0.35^{\mathrm{Bb}}$ & 0.02 \\
\hline & 4 week & $0.76^{\mathrm{a}}$ & $0.70^{\mathrm{a}}$ & $0.71^{\mathrm{a}}$ & $0.69^{\mathrm{a}}$ & 0.01 \\
\hline & SE & 0.05 & 0.06 & 0.07 & 0.08 & \\
\hline
\end{tabular}

\footnotetext{
${ }^{1)}$ Treatments are the same as in Table 1.

${ }^{A-C}$ Means with different superscripts in the same row significantly differ at $p<0.05$.

${ }^{\mathrm{a}-\mathrm{b}}$ Means with different superscripts in the same column significantly differ at $p<0.05$.
} 
저장기간 동안 가열감량이 증가하였으나 유의적인 변화가 없 었다. 저장 4 주째의 모든 시험구의 가열감량의 유의적인 차이 가 나타나지 않았다. 전단가의 경우 제초초기 $\mathrm{T} 2$ 및 $\mathrm{T} 3$ 가 대조 구 및 $\mathrm{T} 1$ 보다 유의적으로 낮게 나타났으며, $\mathrm{T} 3$ 가 가장 낮은 전단가를 나타내어 가장 연한 게맛살 특성을 나타내었다. 하지 만 T1은 대조구와 유의적인 차이를 나타내지 않았다. 제조초기 및 저장 4 주간의 전단가 비교에서 저장기간 증가에 따라 모든 시험구의 전단가가 유의적으로 증가하였다 $(\mathrm{p}<0.05)$. 하지만 저 장 4 주차에 모든 시험구의 전단가의 유의적인 차이가 나타나 지 않았다. 이상의 결과 $\mathrm{T} 3$ 처리구가 제조초기 보수력, 가열감 량 및 전단가 특성 면에서 $\mathrm{T} 1$ 및 $\mathrm{T} 2$ 처리구와 차이를 보이는 것은 유지 및 분말이라는 첨가 물성차이로 사료된다. 이러한 결과는 CLA와 같은 유지의 첨가 시 유화 구조 형성이 충분하 게 이루어지지 않을 경우 게맛살 내부 조직력에 일부 영향을 미칠 것으로 사료된다. 식육에서 $\mathrm{pH}$ 는 육색, 연도, 보수력에 중요한 영향을 미치며[ 9] $\mathrm{pH}$ 의 증가는 일반적으로 식육의 연 도와 보수력을 증가시키는데, 본 연구결과 CLA의 첨가에 의한 $\mathrm{pH}$ 의 증가는 폐계육 게맛살의 보수력과 가열감량에 영향을 미치지 않는 것으로 사료된다. 이러한 이유는 사후 근육에서의 $\mathrm{pH}$ 의 변화와 해당작용과 같은 사후 대사 작용이 게맛살과 같 은 가공제품에서 발생이 적었기 때문인 것으로 사료된다.

\section{육색}

기능성 물질 첨가에 따른 폐계육 함유 게맛살의 육색은 Table 5에 나타내었다. 제조초기에 밝기를 나타내는 명도 $\mathrm{L}^{*}$ 및 백색도를 나타내는 $\mathrm{W}$ 는 $\mathrm{T} 1$ 과 $\mathrm{T} 2$ 가 유의적으로 낮아지는 결과를 나타내었으며, 저장 4 주째에는 명도 및 백색도에서 $\mathrm{T} 1$ 이 가장 낮은 값을 나타내었다 $(\mathrm{p}<0.05)$. 적색도 $\left(\mathrm{a}^{*}\right)$ 와 황색도 $\left(\mathrm{b}^{*}\right)$ 는 제조초기 및 저장 4 주차에 $\mathrm{T} 2$ 및 $\mathrm{T} 3$ 처리구가 유의적으 로 낮은 값을 나타내었으나, T1은 대조구와 유의적인 차이를 나타내지 않았다. 저장기간 동안 CLA 첨가구 $\mathrm{T} 3$ 이 가장 안정 된 밝기, 백색도, 적색도 및 황색도의 변화를 나타내었다. 하지 만, 모든 처리구의 명도 및 백색도는 증가하는 경향이었다. Chen (2002)은 수리미에 있어 백색도는 가장 중요한 품질요소 중에 하나라고 보고하였는데, 본 실험결과 CLA 첨가구(T3)가 대조구와 함께 다른 처리구에 비교해 높은 명도와 백색도를 나타냄으로써 육색측면에서 우수하한 것으로 사료되며, T3군 은 또한 저장기간 동안 육색이 안정되어 다른 시험구보다 우 수하였다.

\section{겔 특성}

기능성 물질 첨가에 따른 폐계육 함유 게맛살의 겔특성 변 화는 Table 6에 나타내었다. 제조초기 및 저장 4 주차의 파괴강 도, 겔강도 및 젤리 강도는 모든 처리구가 유의적으로 낮게 나타났다 $(\mathrm{p}<0.05)$. 또한 제조초기 CLA 첨가구(T3)가 다른 처 리구에 비교해 유의적으로 낮은 파괴강도와 겔강도 및 젤리강 도를 나타내었으나 $(\mathrm{p}<0.05)$. 제조초기 및 저장 4 주차에 변형도 는 시험구 간 유의적인 차이를 나타내지 않았다. 저장기간 증 가에 따른 겔특성의 변화에서 $\mathrm{T} 3$ 처리구는 파괴강도, 겔 강도 및 젤리강도가 증가하는 경향을 나타내었으나, $\mathrm{T} 1$ 처리구는 파괴강도와 겔 강도가 감소하는 경향을 나타내었다 $(\mathrm{p}<0.05)$. 하지만 저장기간의 증가에 따른 대조구 및 $\mathrm{T} 2$ 는 파괴강도, 젤 강도 및 젤리강도의 유의적인 변화가 나타나지 않았다. 본 연 구에서 조직감 특성(Table 6)은 $\mathrm{T} 2$ 처리구가 전체적으로 높은 경향을 나타내었으나 전체적인 겔특성은 대조구가 높은 것으 로 나타났으며, $\mathrm{T} 3$ 처리구가 낮은 겔특성을 나타내었다. 이러 한 이유는 CLA와 같은 지방질 원료의 첨가가 단백질과 유화

Table 5. Impact of functional components addition on meat color of crab meat analog

\begin{tabular}{|c|c|c|c|c|c|c|}
\hline \multirow{2}{*}{ Items } & \multirow{2}{*}{ Storage } & \multicolumn{5}{|c|}{ Treatments ${ }^{1)}$} \\
\hline & & $\mathrm{C}$ & $\mathrm{T} 1$ & $\mathrm{~T} 2$ & T3 & SE \\
\hline \multirow{3}{*}{$\mathrm{L}^{*}$} & 1 day & $81.35^{\mathrm{Ab}}$ & $76.95^{\mathrm{C}}$ & $79.00^{\mathrm{Bb}}$ & $80.87^{\mathrm{A}}$ & 0.57 \\
\hline & 4 week & $82.31^{\mathrm{Aa}}$ & $77.19^{\mathrm{B}}$ & $80.10^{\mathrm{Aa}}$ & $80.97^{\mathrm{A}}$ & 0.59 \\
\hline & SE & 0.24 & 0.14 & 0.29 & 0.13 & \\
\hline \multirow{3}{*}{$a^{*}$} & 1 day & $2.23^{A}$ & $2.45^{\mathrm{Ab}}$ & $1.86^{\mathrm{C}}$ & $2.05^{\mathrm{B}}$ & 0.09 \\
\hline & 4 week & $2.27^{\mathrm{A}}$ & $2.61^{\mathrm{Aa}}$ & $1.87^{\mathrm{C}}$ & $2.01^{B}$ & 0.11 \\
\hline & SE & 0.02 & 0.04 & 0.02 & 0.01 & \\
\hline \multirow{3}{*}{$b^{*}$} & 1 day & $3.39^{\mathrm{A}}$ & $4.22^{\mathrm{Aa}}$ & $3.06^{C}$ & $3.38^{B}$ & 0.18 \\
\hline & 4 week & $3.32^{\mathrm{A}}$ & $3.68^{\mathrm{Ab}}$ & $2.79^{B}$ & $3.03^{B}$ & 0.15 \\
\hline & SE & 0.03 & 0.15 & 0.08 & 0.10 & \\
\hline \multirow{3}{*}{ W } & 1 day & $71.18^{\mathrm{Ab}}$ & $64.28^{\mathrm{Cb}}$ & $69.82^{\mathrm{Bb}}$ & $70.72^{\mathrm{A}}$ & 1.01 \\
\hline & 4 week & $72.36^{\mathrm{Ba}}$ & $66.15^{\mathrm{Ba}}$ & $71.72^{\mathrm{Aa}}$ & $71.89^{\mathrm{A}}$ & 0.97 \\
\hline & SE & 0.28 & 0.47 & 0.47 & 0.35 & \\
\hline
\end{tabular}

\footnotetext{
${ }^{1)}$ Treatments are the same as in Table 1.

${ }^{A-C}$ Means with different superscripts in the same row significantly differ at $p<0.05$.

${ }^{a-b}$ Means with different superscripts in the same column significantly differ at $p<0.05$. ${ }^{*} \mathrm{~W}=\mathrm{L}^{*}-3 \mathrm{~b}{ }^{*}$
} 
Table 6. Impact of functional components addition on gel characteristics of crab meat analog

\begin{tabular}{|c|c|c|c|c|c|c|}
\hline \multirow{2}{*}{ Items } & \multirow{2}{*}{ Storage } & \multicolumn{5}{|c|}{ Treatments $^{1)}$} \\
\hline & & C & T1 & T2 & T3 & SE \\
\hline \multirow{3}{*}{ Breaking force $(\mathrm{g})$} & 1 day & $254.00^{\mathrm{A}}$ & $213.00^{\mathrm{Ba}}$ & $213.00^{\mathrm{B}}$ & $143.33^{\mathrm{Cb}}$ & 12.57 \\
\hline & 4 week & $255.67^{\mathrm{A}}$ & $183.67^{\mathrm{Db}}$ & $243.00^{B}$ & $205.67^{\mathrm{Ca}}$ & 8.87 \\
\hline & SE & 2.26 & 7.24 & 8.84 & 14.71 & \\
\hline \multirow{3}{*}{$\begin{array}{l}\text { Deformation } \\
\quad(\mathrm{mm})\end{array}$} & 1 day & 7.82 & 6.53 & 6.60 & 5.65 & 0.29 \\
\hline & 4 week & 8.43 & 6.72 & 6.42 & 6.72 & 0.16 \\
\hline & SE & 0.29 & 0.30 & 0.15 & 0.39 & \\
\hline \multirow{3}{*}{$\begin{array}{l}\text { Gel strength } \\
\left(\mathrm{g} / \mathrm{cm}^{2}\right)\end{array}$} & 1 day & $1293.61^{\mathrm{A}}$ & $1084.80^{\mathrm{Ba}}$ & $1084.80^{\mathrm{B}}$ & $729.99^{\mathrm{Cb}}$ & 64.02 \\
\hline & 4 week & $1302.10^{\mathrm{A}}$ & $935.41^{\mathrm{Db}}$ & $1237.59^{B}$ & $1047.45^{\mathrm{Ca}}$ & 45.17 \\
\hline & SE & 11.50 & 36.88 & 45.00 & 74.89 & \\
\hline \multirow{3}{*}{$\begin{array}{l}\text { Jelly strength } \\
\text { (g*mm) }\end{array}$} & 1 day & $1988.37^{\mathrm{A}}$ & $1398.07^{\mathrm{B}}$ & $1412.40^{\mathrm{B}}$ & $819.33^{\mathrm{Cb}}$ & 122.31 \\
\hline & 4 week & $2158.33^{\mathrm{A}}$ & $1233.10^{C}$ & $1559.92^{\mathrm{B}}$ & $1378.18^{\mathrm{BCa}}$ & 54.46 \\
\hline & SE & 90.33 & 86.25 & 75.30 & 140.42 & \\
\hline
\end{tabular}

${ }^{1)}$ Treatments are the same as in Table 1.

${ }^{A-C}$ Means with different superscripts in the same row significantly differ at $p<0.05$.

${ }^{a-b}$ Means with different superscripts in the same column significantly differ at $p<0.05$.

*Jelly strength=Breaking force $\times$ Deformation.

물을 형성하는 과정에서 게맛살의 물리적 성질에 영향을 주었 기 때문인 것으로 사료된다.

\section{조직감}

기능성 물질 첨가에 따른 폐계육 함유 게맛살의 조직감은
Table 7에 나타내었다. 누에고치분말 첨가구(T2)는 모든 조직 감 항목에서 다른 처리구에 비교해 유의적으로 높은 수치를 나타내었다 그러나 동충하초분말 첨가구(T1)는 모든 항목에 서 낮은 수치를 나타내었다. 저장 기간에 따른 조직감의 변화 에서, 저장 4 주후 대조구 $(\mathrm{C})$ 와, $\mathrm{T} 1$ 그리고 $\mathrm{T} 2$ 처리구에서 $\mathrm{Gum}$

Table 7. Impact of functional components addition on texture properties of crab meat analog

\begin{tabular}{|c|c|c|c|c|c|c|}
\hline \multirow{2}{*}{ Items } & \multirow{2}{*}{ Storage } & \multicolumn{5}{|c|}{ Treatments ${ }^{1)}$} \\
\hline & & $\mathrm{C}$ & $\mathrm{T} 1$ & $\mathrm{~T} 2$ & T3 & SE \\
\hline \multirow{3}{*}{$\begin{array}{c}\text { Hardness } \\
(\mathrm{kg})\end{array}$} & 1 day & $0.15^{\mathrm{A}}$ & $0.11^{\mathrm{Bb}}$ & $0.14^{\mathrm{Ab}}$ & $0.13^{\mathrm{A}}$ & 0.01 \\
\hline & 4 week & $0.17^{\mathrm{A}}$ & $0.12^{\mathrm{Ba}}$ & $0.17^{\mathrm{Aa}}$ & $0.12^{\mathrm{B}}$ & 0.01 \\
\hline & SE & 0.01 & 0.00 & 0.01 & 0.00 & \\
\hline \multirow{3}{*}{$\begin{array}{l}\text { Brittleness } \\
\qquad(\mathrm{kg})\end{array}$} & 1 day & $0.15^{\mathrm{A}}$ & $0.10^{\mathrm{Bb}}$ & $0.14^{\mathrm{Ab}}$ & $0.13^{\mathrm{A}}$ & 0.01 \\
\hline & 4 week & $0.17^{\mathrm{A}}$ & $0.12^{\mathrm{Ba}}$ & $0.17^{\mathrm{Aa}}$ & $0.11^{\mathrm{B}}$ & 0.01 \\
\hline & SE & 0.01 & 0.01 & 0.01 & 0.01 & \\
\hline \multirow{3}{*}{$\begin{array}{c}\text { Cohesiveness } \\
\text { (\%) }\end{array}$} & 1 day & $1.11^{\mathrm{A}}$ & $0.62^{\mathrm{Bb}}$ & $1.47^{\mathrm{A}}$ & $1.25^{\mathrm{Aa}}$ & 0.13 \\
\hline & 4 week & $1.21^{\mathrm{B}}$ & $1.60^{\mathrm{Aa}}$ & $1.54^{\mathrm{A}}$ & $0.53^{\mathrm{Cb}}$ & 0.18 \\
\hline & SE & 0.05 & 0.22 & 0.04 & 0.17 & \\
\hline \multirow{3}{*}{$\begin{array}{l}\text { Springiness } \\
(\mathrm{mm})\end{array}$} & 1 day & $1.92^{\mathrm{B}}$ & $1.15^{\mathrm{Cb}}$ & $2.52^{\mathrm{A}}$ & $2.11^{\mathrm{Ba}}$ & 0.21 \\
\hline & 4 week & $1.94^{\mathrm{B}}$ & $2.33^{\mathrm{Aa}}$ & $2.29^{\mathrm{A}}$ & $1.03^{\mathrm{Bb}}$ & 0.22 \\
\hline & SE & 0.05 & 0.27 & 0.09 & 0.25 & \\
\hline \multirow{3}{*}{$\begin{array}{c}\text { Gumminess } \\
(\mathrm{kg})\end{array}$} & 1 day & $0.16^{\mathrm{Bb}}$ & $0.07^{\mathrm{Cb}}$ & $0.21^{\mathrm{Ab}}$ & $0.16^{\mathrm{Ba}}$ & 0.02 \\
\hline & 4 week & $0.20^{\mathrm{Ba}}$ & $0.19^{\mathrm{Ba}}$ & $0.26^{\mathrm{Aa}}$ & $0.06^{\mathrm{Cb}}$ & 0.03 \\
\hline & SE & 0.01 & 0.03 & 0.01 & 0.02 & \\
\hline \multirow{3}{*}{$\begin{array}{l}\text { Chewiness } \\
(\mathrm{kg}, \mathrm{mm})\end{array}$} & 1 day & $0.32^{\mathrm{Bb}}$ & $0.08^{\mathrm{Cb}}$ & $0.53^{\mathrm{A}}$ & $0.34^{\mathrm{Ba}}$ & 0.07 \\
\hline & 4 week & $0.40^{\mathrm{Ba}}$ & $0.45^{\mathrm{Ba}}$ & $0.60^{\mathrm{A}}$ & $0.07^{\mathrm{Cb}}$ & 0.08 \\
\hline & SE & 0.02 & 0.08 & 0.03 & 0.06 & \\
\hline \multirow{3}{*}{$\begin{array}{l}\text { Adhesiveness } \\
\qquad(\mathrm{kg}, \mathrm{f})\end{array}$} & 1 day & $0.04^{\mathrm{A}}$ & $0.03^{\mathrm{B}}$ & $0.04^{\mathrm{Ab}}$ & $0.04^{\mathrm{A}}$ & 0.00 \\
\hline & 4 week & $0.04^{\mathrm{B}}$ & $0.04^{\mathrm{B}}$ & $0.05^{\mathrm{Aa}}$ & $0.04^{\mathrm{B}}$ & 0.00 \\
\hline & SE & 0.00 & 0.00 & 0.00 & 0.00 & \\
\hline
\end{tabular}

${ }^{1}$ Treatments are the same as in Table 1.

${ }^{\text {A-C }}$ Means with different superscripts in the same row significantly differ at $p<0.05$.

${ }^{a-b}$ Means with different superscripts in the same column significantly differ at $p<0.05$. 
성이 유의적으로 증가하는 경향을 나타내었다. 그러나 $\mathrm{T} 3$ 처 리구는 저장기간의 증가에 따라 경도, 파쇄성, Gum성, 저작성 그리고 부착성이 유의적으로 감소하였다. 검성이란 식품을 삼 킬 수 있는 정도를 저작하는데 필요한 에너지로 Gum성이 높 을수록 삼키는데 많은 저작을 필요로 한다. $\mathrm{T} 2$ 처리구는 Gum 성을 포함한 모든 측정항목에서 유의적으로 높은 수치를 나타 냄으로써 다른 처리구에 비교해 좀더 강한 조직력을 가지고 있는 것으로 사료된다. 본 연구결과 CLA 첨가구(T3)가 저장기 간의 경과에 따라 응집성, 탄력성, Gum성 및 저작성 수치가 감소하였는데 이러한 이유는 원료 고유의 함유된 지방보다 인위적으로 첨가된 지방의 미끄러운 성질이 기계를 이용한 측정 시 일부 작용했기 때문인 것으로 사료된다.

\section{지방산패도, 휘발성염기질소 및 총세균수 변화}

기능성 물질 첨가에 따른 폐계육 함유 게맛살의 지방산패 도, 단백질변패도, 및 총세균수는 Table 8 에 나타내었다. 지방 산패도(TBA)와 휘발성염기질소( $\mathrm{VBN})$ 는 처리구간의 유의적 인 차이가 나타나지 않았다. 그러나 모든 처리구에서 저장기 간의 경과에 의해 $\mathrm{TBA}$ 값은 감소하였고, $\mathrm{VBN}$ 값과 총세균수 는 증가하는 경향을 나타내었다. 저장 4 주경과 후 총 미생물수 는 2 3배 증가하였고, 단백질변패도는 8 9배 증가하였다. 본 실험결과 단백질 변패도가 크게 증가한 이유는 게맛살의 특성상 단백질 함량이 높기 때문에 지방에 비해 상대적으로 변패할 물질의 함량이 높기 때문인 것으로 사료된다. 그러나 기능성 물질의 종류에 따라 단백질 변패도와 지방산패도는 영향을 받지 않는 것으로 나타났다. 총세균수는 제조초기에 CLA 첨가구(T3)가 다른 처리구에 비교해 유의적으로 높게 나 타났으나 저장 4 주후에는 가장 유의적으로 낮은 미생물수를 나타내었다. 이러한 효과는 CLA와 같은 지방산의 첨가에 따 른 효과라고 사료된다. Bibel 등(1989)은 유리지방산이 미생물 의 성장을 억제하는 효과가 있다고 보고하였는데, 본 실험에 첨가한 유리지방산 형태의 CLA가 미생물을 억제하는 효과를
나타낸 것으로 추측된다. 그러나 CLA가 미생물을 억제하는 작용은 아직 보고된 바 없으며 이러한 효과는 CLA의 직접적 인 효과보다는 유리지방산 자체의 효과라고 판단되어진다. 따 라서 CLA 첨가가 폐계육 함유 게맛살 제조시 관능적 품질에 영향을 주지 않는다는 조건하에서 미생물 억제효과를 가질 수 있고, 또한 CLA가 가지고 있는 항암효과와 같은 다양한 생리활성 기능을 기대할 수 있을 것으로 사료된다.

\section{관능검사}

기능성 물질 첨가에 따른 폐계육 함유 게맛살의 관능검사 결과 변화는 Table 9에 나타내었다. 관능검사 결과 제조초기 및 저장 4 주후의 전체적인 기호도를 포함한 육색, 향, 풍미, 연도 및 다즙성 모든 항목에서 처리구간의 유의적인 차이가 나타나지 않았으며, 저장기간별 비교에서도 주목할 만한 경향 을 나타내지 않았다. 본 실험 결과 기능성 물질의 첨가가 기계 적인 품질 측정항목에서는 기능성 물질의 종류와 저장기간에 따른 유의적인 차이를 나타내었지만 관능적 품질에는 크게 영향을 미치지 않는 것으로 나타났다. 이러한 이유는 기계적 인 수치의 차이가 사람의 감각기관을 통해 구별할 수 있는 수준보다 민감하기 때문인 것으로 사료되며 또한 폐계육 함유 게맛살을 제조시 첨가한 소금, 설탕, 인산염과 같은 복합 향신 료의 첨가가 이러한 맛의 차이를 덮어버리는 masking 효과를 나타내었기 때문인 것으로 사료된다. 일반적으로 사람이 조리 한 음식을 섭취할 때 식품에 첨가된 소금이나 설탕과 같은 여러 가지 향신료는 입안에서 침의 분비를 증가시켜 관능검사 시 다즙성을 비롯한 풍미에 영향을 미치게 되며, 혀의 감각기 관을 자극하여 향신료를 제외한 원료 고유의 맛을 느끼는 것 을 방해할 수 있다. 따라서 폐계육 함유 게맛살 제조시에 첨가 한 기능성 물질의 종류에 따라 이화학적인 특성의 차이가 나 타난다 하더라도 향신료를 첨가한 완제품의 제조시에는 동충 하초분말이나 누에고치분말 및 CLA 급여가 폐계육을 함유한 게맛살의 관능적인 품질에 크게 영향을 미치지 않으므로 이러

Table 8. Impact of functional components addition on TBARS, VBN and microorganisms of crab meat analog

\begin{tabular}{|c|c|c|c|c|c|c|}
\hline \multirow{2}{*}{ Items } & \multirow{2}{*}{ Storage } & \multicolumn{5}{|c|}{ Treatments ${ }^{1)}$} \\
\hline & & $\mathrm{C}$ & T1 & $\mathrm{T} 2$ & T3 & SE \\
\hline \multirow{3}{*}{ TBARS (mg/100g) } & 1 day & $0.54^{\mathrm{a}}$ & $0.59^{\mathrm{a}}$ & $0.58^{\mathrm{a}}$ & $0.56^{\mathrm{a}}$ & 0.01 \\
\hline & 4 week & $0.44^{\mathrm{b}}$ & $0.43^{\mathrm{b}}$ & $0.45^{\mathrm{b}}$ & $0.45^{\mathrm{b}}$ & 0.01 \\
\hline & SE & 0.02 & 0.04 & 0.03 & 0.03 & \\
\hline \multirow{3}{*}{ VBN $(m g \%)$} & 1 day & $19.72^{b}$ & $15.10^{b}$ & $12.34^{b}$ & $17.64^{b}$ & 1.21 \\
\hline & 4 week & $162.17^{\mathrm{a}}$ & $134.72^{\mathrm{a}}$ & $121.91^{\mathrm{a}}$ & $148.58^{\mathrm{a}}$ & 8.35 \\
\hline & SE & 28.01 & 27.65 & 24.57 & 30.65 & \\
\hline \multirow{3}{*}{$\begin{array}{c}\mathrm{TPC} \\
\left(\log _{10} \mathrm{CFU}\right)\end{array}$} & 1 day & $1.74^{\mathrm{Bb}}$ & $2.40^{\mathrm{Bb}}$ & $2.23^{\mathrm{Cb}}$ & $3.14^{\mathrm{Ab}}$ & 0.14 \\
\hline & 4 week & $7.11^{\mathrm{Aa}}$ & $6.84^{\mathrm{Aa}}$ & $6.83^{\mathrm{Aa}}$ & $6.64^{\mathrm{Ba}}$ & 0.04 \\
\hline & SE & 1.20 & 0.99 & 1.03 & 0.78 & \\
\hline
\end{tabular}

\footnotetext{
${ }^{1)}$ Treatments are the same as in Table 1.

${ }^{\text {A-C }}$ Means with different superscripts in the same row significantly differ at $p<0.05$.

${ }^{\mathrm{a}-\mathrm{b}}$ Means with different superscripts in the same column significantly differ at $p<0.05$.
} 
Table 9. Impact of functional components addition on sensory score of crab meat analog

\begin{tabular}{|c|c|c|c|c|c|c|}
\hline \multirow{2}{*}{ Items } & \multirow{2}{*}{ Storage } & \multicolumn{5}{|c|}{ Treatments $^{2)}$} \\
\hline & & C & $\mathrm{T} 1$ & $\mathrm{~T} 2$ & T3 & SE \\
\hline \multirow{3}{*}{ Color } & 1 day & $6.33^{1)}$ & $6.42^{\mathrm{a}}$ & 6.17 & 6.67 & 0.12 \\
\hline & 4 week & 6.33 & $5.83^{\mathrm{b}}$ & 6.33 & 6.33 & 0.12 \\
\hline & SE & 0.14 & 0.15 & 0.13 & 0.15 & \\
\hline \multirow{3}{*}{ Odor } & 1 day & 6.08 & 6.25 & 6.58 & 6.83 & 0.26 \\
\hline & 4 week & 6.17 & 5.92 & 5.67 & 6.25 & 0.18 \\
\hline & SE & 0.30 & 0.29 & 0.33 & 0.23 & \\
\hline \multirow{3}{*}{ Taste } & 1 day & 6.67 & 6.50 & $6.50^{\mathrm{a}}$ & 6.58 & 0.14 \\
\hline & 4 week & 6.42 & 5.92 & $5.58^{\mathrm{b}}$ & 5.75 & 0.21 \\
\hline & SE & 0.21 & 0.23 & 0.22 & 0.30 & \\
\hline \multirow{3}{*}{ Tenderness } & 1 day & 5.75 & 6.08 & 6.25 & 6.25 & 0.21 \\
\hline & 4 week & 6.42 & 6.50 & 6.33 & 6.25 & 0.11 \\
\hline & SE & 0.24 & 0.23 & 0.20 & 0.19 & \\
\hline \multirow{3}{*}{ Juiciness } & 1 day & 6.17 & 6.67 & 6.50 & 6.67 & 0.20 \\
\hline & 4 week & 6.00 & 5.92 & 6.25 & 6.00 & 0.08 \\
\hline & SE & 0.23 & 0.20 & 0.22 & 0.20 & \\
\hline \multirow{3}{*}{ Overall acceptability } & 1 day & 6.25 & 6.58 & 6.75 & 6.83 & 0.21 \\
\hline & 4 week & 6.42 & 6.25 & 6.25 & 6.17 & 0.14 \\
\hline & SE & 0.28 & 0.23 & 0.20 & 0.25 & \\
\hline
\end{tabular}

${ }^{1)}$ Sensory scores were assessed on 9 point scale base on $1=$ extremely bad or slight, $9=$ extremely good or much.

${ }^{2)}$ Treatments are the same as in Table 1.

${ }^{\text {A-C }}$ Means with different superscripts in the same row significantly differ at $p<0.05$.

${ }^{a-b}$ Means with different superscripts in the same column significantly differ at $p<0.05$.

\section{한 기능성 물질을 함유한 게맛살의 개발이 가능할 것으로 사} 료된다.

\section{감사의 글}

이 논문은 농림기술개발사업 지원에 의하여 연구된 것으로 이에 감사드립니다.

\section{References}

1. AOAC. 1990. Official methods of analysis. Washington, DC, USA: Association of Official Analytical Chemists.

2. APHA. 1992. Compedium of methods for microbiological examination of foods (p. 914), Washington, DC; American Public Health Association.

3. Bibel, D. J., S. J. Miller, B. E. Brown, B. B. Pandey, P. M. Elias, H. R. Shinefield, and R. Aly. 1989. Antimicrobial activity of stratum corneum lipids from normal and essential fatty acid-deficient mice. J. Invest. Dermatol. 92, 632-638.

4. Buege, J. A. and J. D. Aust. 1978. Microsomal lipid peroxidation. Methods Enzymol. 52, 302-310.

5. Chen, G. Z. and G. L. Chen. 1991. Effects of Cordyceps sinensis on murine T lymphocyte subsets. Chin. Med. J. 104, 4.

6. Chen, H. H 2002. Decoloration and gel-forming ability of horse mackerel mince by air-flotation washing. J. Food Sci. 67, 2970-2975.
7. Choi, J. D. and Y. J. Choi. 2003. Optimum formulation of starch and non-muscle protein for alkalin surimi gel from Jack mackerel. J. Korean Soc. Food Sci. Nur. 37, 1032-1038.

8. Han, D. S., H. N. Song, and S. H. Kim. 1999. silkworm cordyceps: New material of functional food. Food Science and Industry 32, 56-63.

9. Honikel, K. O. 1987. The water binding of meat. Fleischwirtschaft 67, 1098-1102.

10. Huang, H., H. Wang, and R. C. Luo. 2007. Inhibitory effects of cordyceps extract on grow of colon cancer cells. Zhong Yao Cai 30, 310-313.

11. Ji, S. D., K. H. Shin, D. K. Han, and S. Y. Cho. 2003. The mass production technology and pharmachological effect of silkworm cordyceps(Peacilomyces tenuipes). Food Science and Industry 36, 38-48.

12. Kiho, T., A. Yamane, S. Hui and S. Ukai. 1996. Polysaccharide (CS-F30) from the cultural mycelium of Cordyceps sinensis and its effect on gluco metabolism in mouse liver. Biol. Pharm. Bull 16, 291.

13. Kneifel, H., W. A. King, W. Loeffler, and R. Miller. 1977. Ophiocordin, and antifungal antibiotics of Cordyceps ophioglossoides. Arch. Mocrobiol. 113, 121.

14. Korea Food and Drug Administration. 1998. Gazette material acception of Silk Worm Dongchunghacho.

15. Kuo, Y. C., W. J. Tsai, M. S. Shiao, C. F. Chen, and C. Y. Lin. 1996. Cordyceps sinensis as an immunomodula tory agent. J. Chin. Med. XXIV(2), 111

16. Kye, P. L. and Y. E. Jin. 1994. Many-sided develop of Dog 
Use. Silk Science and Technology 32, 24-27.

17. Lee, H. M., Y. J. Kim, H. W. Kim, D. H. Lee, M. K. Sung, and T. S. Park. 2006. Induction of apoptosis by Cordyceps militaris through activation of caspase-3 in leukemia HL-60 cells. Biol. Pharm. Bull. 29, 670-674.

18. Lee, J. R., Y. J. Ha, J. W. Lee, Y. M. Song, S. K. Jin, I. S, Kim, K. H. Hah, and S. J. Kwak. 2002 Physico-chemical and sensory properties of emulsified sausage containing mulberry and persimmon leaf powder. Korean J. Food Sci. Ani. Resour 22, 330-336.

19. Lee, Y. W. 1991. Method and preparation of silk powder. Kor. J. Monthly Seric. 16, 16-21.

20. Liu, Y., C. Wu, and C. Li. 1991. Antioxidation of Paesilomyces sinensis (S. pnov). Chin. Med. J. 16, 240.

21. Luo, Y., R. Kuwahara, M. Kaneniwa, Y. Murata, and M. Yokoyama. 2004. Effect of soy protein isolate on gel properties of Alaska Pollack and common carp surimi at different setting conditions. J. Sci. Food Agri. 84, 663-671.

22. Miyazaki, T., N. Oikawa, and H. Yamada. 1977. Studies on fungal (Penicillium chrysogenum) polysaccharides. XX. Galactomannan of Cordyceps sinensis (Lepi doptera). Chem. Pharm. Bull. 25, 3324.

23. Pariza, M. W. 2004. Perspective on the safety and effectiveness of conjugated linoleic acid. Am. J. Clin. Nutr. 79, $1132-1136$.

24. Rao, Y. K., S. H. Fang, and Y. M. Tzeng. 2007. Evaluation of the anti-inflammatory and anti-proliferation tumoral cells activites of Antrodia camphorata, Cordyceps sinensis, and Cinnmomum osmophloeum bark extracts. J. Ethnophrmacol. 114, 78-85.

25. Sadaki, O. 1996. The development of functional foods and materials. Biochemistry 13, 44-50.

26. Seed management office, Ministry for Food, Agriculture, Forestry and Fisheries. 1998. Breed license of Silk Worm Dongchunghacho.

27. Shin, K. H. 1999. Bring light and medical action of Silk Worm Dongchunghacho (Report of Rural Development Administration: Exploitation of useful matter and making of Silk Worm Dongchunghacho).

28. Terpstra, A. H. 2004. Effect od conjugated linoleic acid on body composition and plasma lipids in humans: an overview of the literature. Am. J. Clin. Nutr. 79, 352-360.

29. Uddin, M., E. Okazaki, H. Fukushima, S. Turza, Y. Yumiko, and Y. Fukuda. 2006. Nondestructive determination of water and protein in surimi by near-infrared spectroscopy. Food Chem. 96, 491-495.

30. Xu, R. H., X. E. Peng, G. Z. Chen, and G. L. Chen. 1992. Effects of Cordyceps sinensis on naturall killer activity and colony formation of B16 melanoma. Chin. Med. J. 105, 971.

31. Wang, Y. W. and P. J. H. Jones. 2004 Dietary conjugated linoleic acid and body composition. Am. J. Clin. Nutr. 79, 1153-1158.

\section{초록 : 기능성 물질의 첨가가 폐계육이 함유된 게맛살의 저장중 품질에 미치는 영향}

진상근 $\cdot$ 허선진 $^{1} \cdot$ 신택순 $^{2 *}$

(진주산업대학교 동물소재공학과, ${ }^{1}$ 메사추세츠 주립대학 식품과학과, ${ }^{2}$ 부산대학교 동물생명자원과학과)

폐계육 가슴살에서 회수한 단백질을 첨가하여 제조한 게맛살의 저장기간 중 품질의 변화를 측정하였다. 제조 초기 시험구간의 일반성분의 유의적인 차이가 없었으며, 저장이후에도 회분을 제외한 일반성분의 유의적인 차이 가 나타나지 않았다. $\mathrm{pH}$ 는 제조초기 유의적이 차이가 없었으나, 저장 4 주경과 후에 누에고치분말(T2) 및 CLA(T3) 처리구가 다른 시험구에 비해 높게 나타났다. 초기 보수력은 T3가 시험구중 가장 낮았고, 가열감량은 $\mathrm{T} 2$ 및 $\mathrm{T} 3$ 이 가장 낮았고, 전단가는 $\mathrm{T} 2$ 및 $\mathrm{T} 3$ 가 낮게 나타났다. $\mathrm{L}^{*}$ 및 $\mathrm{W}$ 는 대조구와 $\mathrm{T} 3$ 이 시험구 중 비교적 높게 나타났으며, 적색도 $\left(a^{*}\right)$ 와 황색도 $\left(b^{*}\right)$ 는 $\mathrm{T} 2$ 및 T3이 낮게 나타났으며, $\mathrm{T} 3$ 는 저장기간 동안 육색의 안정을 보였다. 파괴강도, 겔강도 및 젤리 강도는 처리구가 대조구에 비하여 낮게 나타났으며, T3가 시험구중 가장 낮은 파괴강 도, 겔강도 및 젤리강도를 나타내었다. 조직감 중 $\mathrm{T} 2$ 가 모든 항목에서 다른 처리구에 비해 높은 수치를, $\mathrm{T} 1$ 은 낮 은 수치를 나타내었다. 특히, $\mathrm{T} 3$ 은 저장기간 동안 경도, 파쇄성, 검성, 저작성 및 부착성이 유의적으로 감소하였 다. 지방산패도(TBA)와 휘발성염기질소(VBN)는 처리구간의 유의적인 차이가 나타나지 않았다. 그러나 모든 처 리구에서 저장기간의 경과에 의해 $\mathrm{TBA}$ 값은 감소하였고, $\mathrm{VBN}$ 값과 총세균수는 저장기간의 증가에 따라 유의적으 로 증가하였다. 관능검사 결과 전체적인 기호도를 포함한 육색, 향, 풍미, 연도 및 다즙성 모든 항목에서 처리구간 의 유의적인 차이가 나타나지 않았다. 본 실험 결과 기능성 물질의 첨가가 기계적인 품질 측정항목에서의 차이에 도 불구하고 관능적 품질에는 크게 영향을 미치지 않는 것으로 나타났으며, 기계적인 품질 측정항목에서는 전체 적으로 $\mathrm{T} 3$ 이 다른 처리구에 비교해 품질의 차이가 많이 나는 것으로 나타났다. 